\title{
Dampak Pendekatan Realistic Mathematics Education Terhadap Keterampilan Berpikir Kritis Pada Siswa Sekolah Dasar
}

\author{
${ }^{1}$ Vivi Puspita, ${ }^{2}$ Nofri Yuhelman and ${ }^{3}$ Ronal Rifandi \\ ${ }^{1}$ PGSD STKIP Adzkia, Indonesia \\ ${ }^{2}$ Pendidikan Matematika Universitas Negeri Padang, Indonesia, \\ ${ }^{3}$ Pendidikan Kimia, Universitas Islam Kuantan Singingi, Indonesia \\ Vivipuspita.pendas@gmail.com //Nofriyuhelma@gmail.com/Ronal rifandi@yahoo.com
}

\section{ARTICLE INFO}

Article History:

Received : 19-09-2018

Revised : 03-11-2018

Accepted : 18-11-2018

Online : $30-11-2018$

Keywords:

Learning mathematic;

Critical thinking;

Realistic mathematic

education

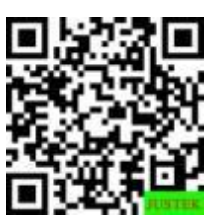

\section{ABSTRACT}

Abstract: The low ability of students in solving math problems illustrates the low ability of students in critical thinking. So this research aims to determine the impact of a realistic approach to mathematics education on students' critical thinking abilities. This research is a quasi experimental study with the type of non-equivalent control group design. The research subjects were 29 elementary school students. The results showed t-hitung $=6.52$ and $\mathrm{t}$-tabel $=1.69092$ where $\mathrm{t}$-hitung is greater than the tabel so that there is a positive influence of the use of Realistic Mathematics Education on the thinking skills of elementary school students, especially in mathematics learning

\begin{abstract}
Abstrak: Rendahnya kemampuan siswa dalam menyelesaikan masalah matematika menggambarkan rendahnya kemampuan berpikir kritis siswa. Maka penelitian ini bertujuan untuk mengetahui pengaruh pendekatan realistik pendidikan matematika terhadap kemampuan berpikir kritis siswa. Penelitian ini merupakan penelitian eksperimental semu dengan jenis desain non-equivalent control group. Subjek penelitian adalah 29 siswa Sekolah Dasar. Hasil penelitian menunjukkan $t_{\text {hitung }}=6,52$ dan $t_{\text {tabel }}=1,69092$ dimana $t_{\text {hitung lebih }}$ besar dari pada $t_{\text {tabel }}$ sehingga ada pengaruh positif penggunaan Pendidikan Matematika Realistik terhadap keterampilan berpikir siswa sekolah dasar, khususnya dalam pembelajaran matematika
\end{abstract}

\section{A. LATAR BELAKANG}

Kemampuan berfikir secara kritis merupakan salah satu kecakapan hidup yang yang perlu dipelajari dan dikembangkan Glaser (Fisher, 2008) berfikir kritis dipandangan sebagai suatu sikap berfikir secara mendalam tentang masalah-masalah dan hal-hal yang berada dalam jangkauan pengalaman seseorang. (Delina et al., 2018) menjelaskan keterampilan berpikir kritis sebangai pengetahuan tentang metode-metode pemeriksaan dan penalaran yang logis dan keterampilan untuk menerapkan metodemetode tersebut. Berfikir kritis menuntut upaya keras untuk memeriksa setiap keyakinan atau pengetahuan asumtif berdasarkan bukti pendukungnya dan kesimpulankesimpulan (Anwar \& Puspita, 2018) lanjutan yang diakibatkannya. senada juga 
dijelaskan Cottrell (Cottrell, 2005) menjelaskan berpikir kritis sebagai aktivitas kognitif, yang terkait dengan penggunaan pikiran. (Cahyana et al., 2017) menjelaskan keterampilan berpikir kritis sebagai proses mental seperti memecahkan masalah, mengambil keputusan, membujuk, menganalisis asumsi dan melakukan penelitian ilmiah.

Upaya memfasilitasi agar kemampuan berpikir kritis siswa berkembang menjadi sangat penting, mengingat beberapa hasil penelitian masih mengindikasikan rendahnya kemampuan berpikir kritis siswa (Dinni, 2018). belum adanya perancangan pembelajaran berfikir kritis di sekolah (Hidayati, 2017). terhadap 16 Sekolah Lanjutan Tingkat Pertama pada beberapa provinsi di Indonesia menunjukkan hasil tes mata pelajaran matematika sangat rendah, utamanya pada soal cerita matematika (aplikasi matematika). Kemampuan aplikasi merupakan bagian dari domain kognitif yang lebih rendah daripada kemampuan analisis, sintesis, dan evaluasi. Ketiga kemampuan tersebut digolongkan oleh Bloom dalam kemampuan berpikir kritis (Runisah, 2019). Pendekatan pengajaran yang bertitik tolak dari hal-hal yang 'real' bagi siswa, menekankan dan menekankan pada keterampilan 'proses of doing mathematics' dinamakan dengan pembelajaran realistik mathematik education (Puspita, 2016). Pada pelaksanaannya kegiatan dilakukan dengan berdiskusi dan berkolaborasi, berargumentasi dengan teman sekelas guna mencapai penemuan (student inventing). Akhirnya menggunakan matematika dilakukan guna menyelesaikan masalah baik secara individu maupun kelompok.

Merujuk penjelasan di atas maka peran guru tak lebih dari seorang fasilitator, moderator atau evaluator guna mengaktifkan keterampilan siswa dalam berfikir, mengkomunikasikan, dengan demikian nuansa demokrasi dengan menghargai pendapat orang lain. Manfaat penggunakan pendekatan RME (Delina et al., 2018)Pelajaran menjadi cukup menyenangkan bagi siswa dan suasana tegang tidak tampak sehingga sebagian besar siswa dapat memahami materi dengan baik. Alat peraga sebagai alat bantu pembelajaran berada di lingkungan sekitar, sehingga mudah didapatkan (Hidayat \& Iksan, 2015).

Dapat disimpulkan saat pembelajaran matematika metode yang digunakan dalam pembelajaran masih berpusat kepada guru. Hal ini menyebabkan siswa tidak aktif dalam belajar, suasana belajar tidak menyenangkan, karena siswa hanya berkonsenterasi pada penjelasan dan mencatat apa yang diberikan oleh guru. Akibatnya siswa kurang paham dengan pembelajaran matematika, siswa tidak mampu memecahkan masalah yang diberikan oleh guru, siswa kurang mampu untuk berfikir kritis dalam memecahkan masalah yang dihadapinya. Pembelajaran dilaksanakan secara pasif, guru hanya seolah menuangkan apa yang diketahuinya kepada siswa, ibarat mengisi air ke dalam botol kosong yang siap menerimanya kegiatan tersebut dikenal dengan pembelajaran yang berpusat kepada guru(Kurino, 2017). Hal ini berdampak pada hasil belajar matematika yang masih rendah, meskipun soal-soal yang diberikan oleh guru masih pada tingkatan pengetahuan, namun siswa masih sulit dalam memecahkan masalah yang dihadapinya.

Oleh karena itu, pembelajaran yang bernuansa pemecahan masalah harus dirancang sedemikian rupa sehingga mampu meransang siswa untuk berfikir dan mendorong menggunakan pemikirannya secara sadar untuk memecahkan masalah. Dengan demikian penelitian ini bertujuan untuk mengetahui dampak pendekatan realistic mathematics education terhadap keterampilan berpikir kritis. Dengan demikian diperoleh Hipotesis bahwa terdapat pengaruh penggunaan pendekatan realistic mathematics education terhadap kemampuan berpikir kritis siswa. 


\section{B. METODE PENELITIAN}

Jenis penelitian yang digunakan dalam penelitian ini adalah penelitian kuantitatif. Metode penelitian yang digunakan dalam penelitian ini adalah penelitian eksperimen. Desain penelitian eksperimen yang digunakan dalam penelitian ini adalah dalam bentuk quasy eksperimental design. (Sugiyono, 2011) menyatakan bahwa quasy eksperimental design mempunyai kelompok kontrol tetapi tidak dapat berfungsi sepenuhnya untuk mengontrol variabel-variabel luar yang mempengaruhi pelaksanaan eksperimen. Desain quasy eksperimen yang digunakan dalam penelitian ini yaitu nonequivalent control group design. Penelitian ini didesain menjadi dua kelas yaitu kelas eksperimen dan kelas kontrol. Populasi pada penelitian ini 98 siswa, sampel berjumlah 29 siswa. Kelas eksperimen diberi perlakuan dengan mengunakan pendekatan realistik mathematik education sedangkan kelas kontrol menggunakan pembelajaran konvensional. Instrumen yang digunakan adalah lembar tes atau soal essay keterampilan berpikir kritis siswa yang memenuhi aspek 1) basic clarification, 2) bases for decision, 3) inference, 4) advanced clarification, and 5) strategies and tactics (Susilowati et al., 2017). Selanjutnya diberikan postest kepada kedua sampel untuk melihat ada tidaknya pengaruh pendekatan realistik mathematik eduacation (perlakuan) terhadap kemampuan berfikir kritis siswa.

\section{HaSil Dan Pembahasan}

Berdasarkan penelitian yang telah dilakukan pada kelas sampel, maka diperoleh data mengenai berfikir kritis masalah siswa kelas V SD Negeri 06 Pasar Ambacang Kota Padang pada pembelajaran matematika. Data diperoleh melalui tes akhir yang dilakukan pada akhir penelitian. Soal tes akhir berupa esai sebanyak 10 butir soal jumlah siswa pada kelas eksperimen yang mengikuti tes akhir sebanyak 16 orang dan jumlah siswa kelas kontrol yang mengikuti tes akhir berjumlah 17 orang. Dari tes akhir diperoleh nilai rata-rata $\left(\overline{X)}\right.$ standar deviasi $(S d)$, skor tertinggi $\left(X_{\text {maks }}\right)$ dan skor terendah $\left(X_{\text {min }}\right)$ terlihat pada tabel berikut:

Tabel 1 . Perhitungan data tes akhir kelas sampel

\begin{tabular}{llllll}
\hline \multicolumn{2}{c}{ Kelas sampel N } & \multicolumn{1}{c}{} & \multicolumn{1}{c}{$\boldsymbol{S} \boldsymbol{d}$} & $\boldsymbol{X}_{\text {maks }}$ & $\boldsymbol{X}_{\min }$ \\
\hline Eksperimen & 16 & 80,62 & 44,13 & 100 & 0 \\
Kontrol & 17 & 64,117 & 40,22 & 85 & 5
\end{tabular}

Pada tabel di atas terlihat bahwa rata-rata kemampuan pemecahan masalah matematika siswa kelas eksperimen $(\bar{X}=80,625)$ lebih tinggi dari rata-rata kemampuan pemecahan masalah matematika siswa kelas kontrol $(\bar{X}=64,117)$. Perbandingan ratarata kelas eksperimen dan kelas kontrol dapat dilihat pada grafik berikut ini.

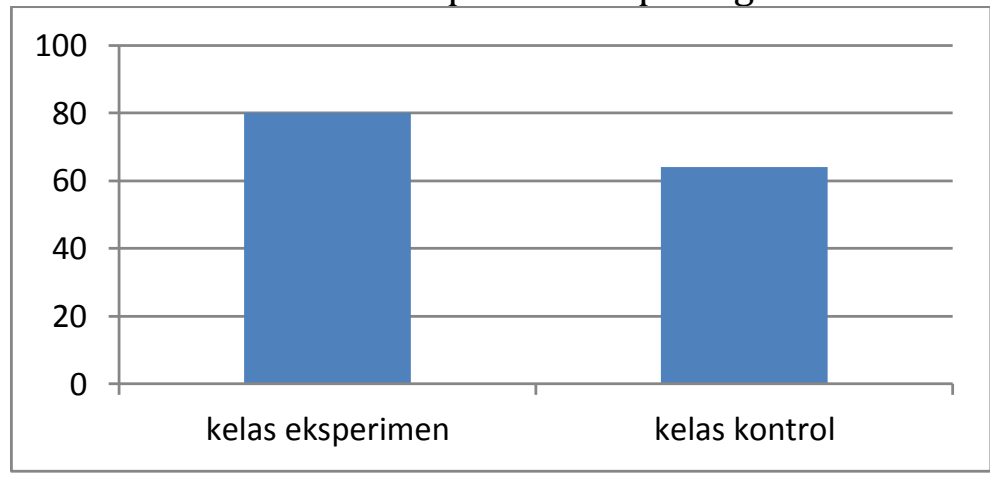

Gambar 1. Diagram Rata-Rata Nilai Kelas Eksperimen dan Kelas Kontrol 
Tujuan analisis data pada penelitian ini adalah untuk mengetahui apakah kemampuan berfikir kritis matematika siswa dengan menggunakan pendekatan RME lebih baik dari pada kemampuan berfikir kritis siswa kelas V SD Negeri 06 Pasar Ambacang Kota Padang. Untuk menguji hipotesis sebelum menarik simpulan, terlebih dahulu data yang dikumpulkan dianalisis. Uji hipotesis yang digunakan adalah uji-t syarat penggunaan uji-t bahwa data harus berasal dari populasi yang berdistribusi normal dan homogen

\section{Uji Normalitas Tes Akhir}

Pada penelitian ini, uji normalitas bertujuan untuk mengetahui apakah data berdistribusi normal atau tidak. Uji normalitas yang dilakukan peneliti menggunakan Software SPSS 22. Hasil uji normalitas yang diperoleh yaitu:

Tabel 2. Hasil Uji Normalitas Tes Kemampuan berfikir kritis Tests of Normality

\begin{tabular}{|c|c|c|c|c|c|c|c|}
\hline \multirow[t]{2}{*}{ Kelas } & & \multicolumn{3}{|c|}{$\begin{array}{l}\text { Kolmogorov- } \\
\text { Smirnov }^{\text {a }}\end{array}$} & \multicolumn{2}{|c|}{ Shapiro-Wilk } & \\
\hline & & $\overline{\text { Statistic } \mathrm{df}}$ & Sig. & & tic df & Sig. & \\
\hline & & .1 & 1 & .2 & .9 & 1 & .749 \\
\hline Kemampuan & A & 51 & 6 & $00^{*}$ & 65 & 6 & \\
\hline berfikir kritis & & .2 & 1 & .0 & .9 & 1 & .157 \\
\hline & B & 27 & 7 & 20 & 22 & 7 & \\
\hline
\end{tabular}

Berdasarkan tabel di atas nilai signifikan yang diperoleh pada keterangan kolom Shapiro-Wilk 0,749 pada kelas eksperimen dan 0,157 pada kelas kontrol > 0,05 (taraf tingkat kesalahan/penolakan), maka dapat dikatakan bahwa data tes kemampuan berfikir kritis berdistribusi normal.

\section{Uji Homogenitas Tes Akhir}

Hasil perhitungan uji homogenitas variansi kedua kelas sampel dengan menggunakan uji lavence dapat dilihat pada tabel di bawah ini:

Tabel 3. Hasil Uji Homogenitas Tes Kemampuan Pemecahan Masalah

\begin{tabular}{cccc}
\hline \multicolumn{4}{c}{ Kemampuan Pemecahan Masalah } \\
\hline Levene Statistic & $\mathrm{df} 1$ & $\mathrm{df} 2$ & Sig. \\
.675 & 1 & 31 & .417
\end{tabular}

Berdasarkan tabel di atas terlihat signifikan dari uji lavence adalah 0,417 > 0,05 (taraf tingkat kesalahan/penolakan) maka dapat dikatakan bahwa data tes kemampuan pemecahan masalah berdistribusi normal. Hasil kemampuan pemecahan masalah matematika siswa yang diajarkan dengan menggunakan pendekatan berfikir kritis lebih tinggi dibandingkan dengan berfikir kritis yang diajarkan dengan metode konvesional. dengan rata-rata berfikir kritis siswa kelas eksperimen $(\bar{X}=80,625)$ lebih tinggi dari rata-rata kemampuan berfikir kritis siswa kelas kontrol $(\bar{X}=64,117)$. Penggunaan pendekataan realistic mathematics education dalam pembelajaran, memberikan kesempatan kepada siswa dalam menganalisis masalah secara mendalam, merancang kegiatan atau strategi penyelesaian menurut pengetahuannya. (Asih, 2017) menjelaskan siswa tidak hanya belajar namun dapat menemukan strategi-strategi penyelesaian masalah serta mengevaluasi teknik-teknik. (Atika \& MZ, 2016) mengungkapkan dengan penggunaan konteks dunia nyata dalam pembelajaran mambu menjembatani siswa dengan matematika, membantu siswa dalam mengkontruksi pemahaman matematika yang bermakna. 


\section{SIMPULAN DAN SARAN}

Berdasarkan hasil penelitian yang peneliti lakukan, dapat diambil kesimpulan

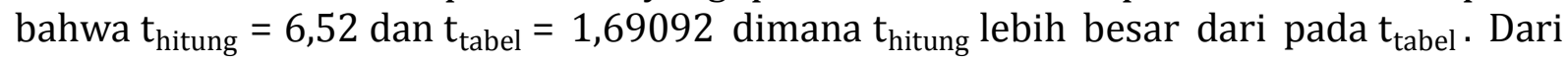
hasil penelitian terbukti bahwa penggunaan pernggunakan pendekatan RME memberikan dampak terhadap kemampuan berfikir kritis siswa sekolah dasar.

\section{UCAPAN TERIMA KASIH}

Ucapan terima Kasih Kepada SD IT Adzkia I dan II Sebagai Tempat melaksanakan Uji coba dan pengambilan data penelitian.

\section{REFERENSI}

Anwar, M., \& Puspita, V. (2018). Analisis Keterampilan Berpikir Tingkat Tinggi Siswa SD IT Adzkia. Seminar Nasional "Pembelajaran Literasi Lintas Disiplin Ilmu Ke-SD-An," November, 186-199. https://www.researchgate.net/publication/329164521_ANALISIS_KETERAMPILA N_BERPIKIR_TINGKAT_TINGGI_SISWA_SD_IT_ADZKIA/link/5bf9186ea6fdcc53881 6c2e8/download

Asih, A. K. E. B. I. \& C. S. (2017). Penerapan Realistic Mathematics Education Untuk Meningkatkan Kemampuan Berpikir Kritis Siswa Kelas V. Jurnal Pendidikan, 2(4), 524-530. http://journal.um.ac.id/index.php/jptpp/article/view/8787

Atika, N., \& MZ, Z. A. (2016). Pengembangan Lks Berbasis Pendekatan Rme Untuk Menumbuhkembangkan Kemampuan Berpikir Kritis Matematis Siswa. Suska $\begin{array}{llll}\text { Journal of Mathematics } & \text { Education, }\end{array}$ https://doi.org/10.24014/sjme.v2i2.2126

Cahyana, U., Kadir, A., \& Gherardini, M. (2017). Relasi Kemampuan Berpikir Kritis Dalam Kemampuan Literasi Sains Pada Siswa Kelas Iv Sekolah Dasar. Sekolah Dasar: Kajian Teori Dan Praktik Pendidikan, 26(1), 14-22. https://doi.org/10.17977/um009v26i12017p014

Cottrell, S. (2005). Critical Thinking Skill. Palgrave Macmillan.

Delina, Afrilianto, M., \& Rohaeti, E. E. (2018). Confidence Siswa Smp Melalui Pendekatan. Jurnal Pembelajaran Matematika Inofatif, 1(3), 281-288. https://doi.org/10.22460/jpmi.v1i3.281-288

Dinni, H. N. (2018). HOTS ( High Order Thinking Skills ) dan Kaitannya dengan Kemampuan Literasi Matematika. Prisma, 1, 170-176.

Fisher, A. (2008). Berfikir Kritis Sebuah Pengantar. Gelora Aksara Pratama.

Hidayat, R., \& Iksan, Z. H. (2015). The Effect of Realistic Mathematic Education on Students' Conceptual Understanding of Linear Progamming. Creative Education, 06(22), 2438-2445. https://doi.org/10.4236/ce.2015.622251

Hidayati, A. U. (2017). TERAMPIL Jurnal Pendidikan dan Pembelajaran Dasar Volume 4 Nomor MELATIH KETERAMPILAN BERPIKIR TINGKAT TINGGI DALAM PEMBELAJARAN MATEMATIKA PADA SISWA SEKOLAH DASAR. Pendidikan Dan Pebelajaran Dasar, 4(20), 143-156.

Kurino, Y. D. (2017). Penerapan Realistic Mathematic Education Dalam Meningkatkan Hasil Belajar Siswa Kelas V Pada Materi Volume Bangun Ruang Di Sekolah Dasar. Jurnal Cakrawala Pendas, 3(2). https://doi.org/10.31949/jcp.v3i2.594

Puspita, V. (2016). Penerapan Pendekatan Realistic Mathematic Education (RME) Sebagai Upaya Meningkatkan Hasil Belajar Matematika Di Kelas IV Sekolah Dasar. 5(1), 65- 
80.

https://jurnal.unimed.ac.id/2012/index.php/handayani/article/view/6351/7418

Runisah, R. R. (2019). Peningkatan Kemampuan Berpikir Kritis Matematis Siswa SMA Melalui SQ3R. Euclid, 6(2), 145. https://doi.org/10.33603/e.v6i2.2216

Sugiyono. (2011). Metode Pennelitian Pendidikan Pendekatan Kuantitatif, Kualitatif, dan $R \& D$. Alfabeta.

Susilowati, Sajidan, \& Ramli, M. (2017). Analisis keterampilan berpikir kritis siswa madrasah aliyah negeri di Kabupaten Magetan. Seminar Nasional Pendidikan Sains 2017 Dengan Tema "Strategi Pengembangan Pembelajaran Dan Penelitian Sains Untuk Mengasah Keterampilan Abad 21 (Creativity and Innovation, Critical Thinking and Problem Solving, Communication, Collaboration/4C)", 21(2000), 223-231. http://www.jurnal.fkip.uns.ac.id/index.php/snps/article/viewFile/11417/8102 